\title{
MDA-MB-231 breast cancer cells overexpressing single VEGF isoforms display distinct colonisation characteristics
}

\author{
Melanie Di Benedetto*,1,2,7, Aurore Toullec 3,4,5,7, Hélène Buteau-Lozano ${ }^{3,4,5}$, Mohamed Abdelkarim ${ }^{1,2}$, \\ Sophie Vacher ${ }^{6}$, Guillaume Velasco ${ }^{3,4,5}$, Monique Christofari ${ }^{3,4,5}$, Marc Pocard ${ }^{3,4,5}$, Ivan Bieche ${ }^{6}$ and \\ Martine Perrot-Applanat ${ }^{\star}, 3,4,5$ \\ ${ }^{1}$ Université Paris 13, A Avenue JB Clément, Villetaneuse, Paris, France; ${ }^{2}$ INSERM UMR1165 Institut Universitaire d'Hématologie, \\ Hôpital Saint-Louis, 1 Avenue Claude Vellefaux, 75010 Paris, France; ${ }^{3}$ INSERM U965, Hôpital Lariboisière-Saint Louis, 75010 Paris, \\ France; ${ }^{4}$ Université Paris-Diderot, 41 boulevard de la Chapelle, 75475 Paris, France; ${ }^{5}$ University of Paris VII, Paris, France and ${ }^{6}$ Unité \\ de Pharmacogénomique, Service de Génétique, Institut Curie, 26 rue d’Ulm, 75248 Paris, France
}

Background: Vascular endothelial growth factor (VEGF) is a multifunctional cytokine that has important roles in angiogenesis. Our knowledge of the significance of VEGF isoforms in human cancer remains incomplete.

Methods: Bioluminescence imaging and transcriptomic analysis were used to study the colonisation capacity of the human breast cancer cells MDA-MB-231 controlling or overexpressing the VEGF165 or VEGF189 isoform (named cV-B, V165-B and V189-B, respectively) in nude mice.

Results: When injected into the bloodstream, V189-B cells induced less metastasis in the lungs and bone than V165-B and cV-B control cells, consistent with longer survival of these mice and delay in tumour uptake in the mice injected with a V189-B clone. Histological analysis confirmed that there were less $\alpha$ SMA-positive cells in the lungs of the mice injected with V189-B. In vitro V189$B$ cells decreased both cell invasion and survival. Using transcriptomic analysis, we identified a subset of 18 genes expressed differentially between V189 and V165 cell lines and in 120 human breast tumours. V165 was associated with poor prognosis, whereas V189 was not, suggesting a complex regulation by VEGF isoforms. Our results showed a negative correlation between the expression pattern of VEGF189 and the levels of expression of seven genes that influence metastasis.

Conclusion: Our findings provide the first evidence that VEGF isoforms have different effects on breast cancer cell line colonisation in vivo.

The vascular endothelial growth factor-A (VEGF-A) is a key regulator of developmental, physiological and pathological neovascularisation, including tumour growth and metastasis (Folkman, 1995; Ferrara and Davis-Smyth, 1997). This growth factor consists of a family of proteins generated from a single gene by alternative splicing of the primary transcript (Tischer et al, 1991). Processing results in human VEGF isoforms consist of proteins $121,145,165,189$ and 206 amino acids. The presence or absence of genomic exons 6 and 7 determines whether these isoforms are secreted in soluble forms (VEGF121 and VEGF165) or remains associated with a cell or extracellular matrix (VEGF189, VEGF206 and to some extent VEGF165) (Gitay-Goren et al, 1992; Park et al, 1993). The VEGF189 has the largest capacity for binding to extracellular matrix components. The most abundant isoforms, VEGF121 and VEGF165, have been the focus of intense studies. Interaction between VEGF isoforms and their endothelial

*Correspondence: Dr M Di Benedetto; E-mail: dibenedetto22@yahoo.fr or Dr M Perrot-Applanat; E-mail: martine.applanat@inserm.fr
${ }^{7}$ These authors contributed equally to this work.

Received 20 October 2014; revised 8 June 2015; accepted 24 June 2015; published online 21 July 2015

(c) 2015 Cancer Research UK. All rights reserved 0007 - 0920/15 
receptors, VEGF-R1 (Flt-1), VEGF-R2 (KDR/Flk-1) and neuropilin-1 (NRP-1), stimulates receptor-associated kinase activity and initiates signalling pathways leading to angiogenesis (Ferrara and Davis-Smyth, 1997; Neufeld et al, 1999; Gille et al, 2001). By contrast, little is known about the role of the cell-associated VEGF189 isoform. In vitro, VEGF189 binds preferentially to VEGF-R1 and NRP-1 (Neufeld et al, 1999; Hervé et al, 2008). The VEGF189 can be cleaved to shorter bioactive forms by proteases, such as plasmin, urokinase plasminogen activator and MMPs (Plouët et al, 1997; Lee et al, 2007). The VEGF189 was recently shown to stimulate the proliferation and migration of endothelial cells (Hervé et al, 2005). Using mouse embryos with low levels of heparin-binding VEGF-A isoform expression $\left(\mathrm{VEGF}^{\mathrm{wt} / 120}\right)$, or expressing only VEGF120 that cannot bind to heparin $\left(\mathrm{VEGF}^{120 / 120}\right)$, Ruhrberg et al (2002) demonstrated the involvement of heparin-binding VEGFs in vascular branching complexity at the earliest stages of angiogenic invasion in several organs. Besides, VEGF189 expression increases in the human endometrium during the secretory phase (Ancelin et al, 2002), suggesting that this isoform also has a role in physiological vascular remodelling during the reproductive process.

Our knowledge of the significance of VEGFA isoform expression in human cancer remains incomplete. Only a few studies have considered the role of the VEGF189 isoform in tumour growth and metastasis. In mouse models, expression of the VEGF165 or VEGF189 isoforms has been associated with differences in tumour growth (Oshika et al, 1998; Tomii et al, 2002; Hervé et al, 2008). Xenograft studies have shown that VEGF189-overexpressing colon cancer cells (SW-480-transfected cells) grow more slowly than VEGF165-overexpressing cells (Hervé et al, 2008); this effect was interpreted as reflecting particular features of VEGF189 molecules. In breast cancers, VEGF165 and VEGF121 were shown to accelerate tumour development (Tomii et al, 2002). We recently showed that VEGF189 contributes to mammary tumour growth through both angiogenic and non-angiogenic functions associated with an autocrine effect on breast cancer cells (Hervé et al, 2008). However, VEGF189-expressing breast cancer cells that delay tumour uptake (Hervé et al, 2008) are less angiogenic and form less rapidly growing xenograft tumours compared with VEGF121expressing cells (Zhang et al, 2000). Different kinds of results were obtained with VEGF189 overexpression, as dilated (Hervé et al, 2008) or thin (Yuan et al, 2011) microvessels were observed, depending on the studies. Several other groups have published on VEGF188-overexpressing fibrosarcomas. Grunstein et al (2000) showed that VEGF188 was associated with hypervascular density but not tumour growth. Tozer et al (2008) showed that fibrosarcomas derived from transgenic mice expressing only VEGF188 under constitutive promoter control developed highly vascularised well-defined tumours. Melanoma cells transfected with VEGF189 remain non-tumourigenic and dormant (Yu et al, 2002). One study, in which VEGF isoform profile was classified into three groups, VEGF121 only (type 1), VEGF121 + 165 (type 2) and VEGF121 + VEGF165 + VEGF189 (type 3) (Tokunaga et al, 1998), showed the higher incidence of liver metastasis in colon cancer patients for the type 3. Higher levels of cell-associated VEGF189 expression were also observed in lung cancers (Yuan et al, 2001). In addition, high levels of the VEGF189 isoform are associated with poor prognosis in lung cancer and osteosarcoma (Lee et al, 1999; Matsuyama et al, 2009), whereas VEGF189 levels are inversely correlated with tumour stage and size in papillary renal cell carcinomas (Jacobsen et al, 2006). Contradictory, results suggest that VEGF189 has a complex role in tumour development and progression.

Therefore, we studied the role of VEGF189 in tumour cell colonisation capacity, which is an important step in the formation of metastasis. To this end, we generated stable human breast carcinoma cell lines (MDA-MB-231) overexpressing the VEGF165 or VEGF189 isoform, named V165 and V189, respectively. The effect of VEGF189 overexpression on the extravasation potential was determined in vivo. We find that VEGF189 expression delays and decreases the colonisation behaviour of V189 cell lines in the lungs and bone. Moreover, analysis of the transcriptomic profiles of our clones identifies genes regulated differently in V189 and V165 cell lines. This study thus provides evidence of a role of VEGF189 in delaying breast cancer cell colonisation.

\section{MATERIALS AND METHODS}

Generation of stable bioluminescent MDA-MB-231 clones overexpressing VEGF isoforms. Human MDA-MB-231 breast cancer cells (ATCC, Molsheim, France) were used to generate stable transfected clones overexpressing VEGF165, VEGF189 or control vector (referred to as V165, V189 and cV, respectively) as previously described (Hervé et al, 2008). Cancer cells were cultured in Dulbecco's modified Eagle's medium (DMEM, Invitrogen, France) supplemented with $10 \%$ fetal bovine serum (FBS; DMEM$10 \% \mathrm{FBS}$ ) and $100 \mu \mathrm{gl}^{-1}$ sodium pyruvate in the presence of antibiotics (100 units per ml penicillin, $100 \mu \mathrm{g} \mathrm{ml}^{-1}$ streptomycin, $500 \mu \mathrm{g} \mathrm{ml}^{-1}$ geneticin G418, Life Technologies). Two clones of each V189, V165 and cV were used to generate stable bioluminescent cells. V165, V189 and cV clones were transfected with a plasmid expressing the luciferase gene and the hygromycin resistance gene (a gift from P. Balaguer, France), in the presence of Fugene 6 reagent, according to the manufacturer's instructions (Roche Diagnostics, Meylan, France). A parallel experiment was performed with a plasmid expressing the GFP gene. Successful gene transfer was confirmed $72 \mathrm{~h}$ after infection, by the visualisation of GFP on fluorescence microscopy. Cells transfected with the luciferase gene plasmid were selected on hygromycin $\left(700 \mu \mathrm{g} \mathrm{ml}^{-1}\right.$; Sigma-Aldrich) in DMEM-10\% FBS. Resistant clones were isolated and maintained in DMEM-10\% FBS supplemented with G418 $\left(500 \mu \mathrm{g} \mathrm{ml}^{-1}\right)$ and hygromycin $\left(300 \mu \mathrm{g} \mathrm{ml}^{-1}\right)$. All cell lines were cultured at $37^{\circ} \mathrm{C}$ in a humidified atmosphere containing $5 \% \mathrm{CO}_{2}$. Luciferase activity was confirmed in vitro by dispensing $1 \times 10^{5}$ cells into complete DMEM in each well of a 96 -well plate. After $24 \mathrm{~h}, \mathrm{D}$-luciferin $\left(150 \mu \mathrm{g} \mathrm{ml}^{-1}\right.$, Caliper) was added to the medium in each well and the plate was incubated for $5 \mathrm{~min}$. Luciferase activity was measured with the IVIS Imaging System (Xenogen, Caliper Life Science, Hopkinton, MA, USA) and analysed with Living Image software, as previously described (Abdelkarim et al, 2009). The clones generated were named V165-B, V189-B and cV-B, according to the construct used for transfection. V189-B31, V165-B45 and cV-B9 cells were selected on the basis of their having equivalent levels of bioluminescence $(104,97$ and 81 photons second per cell, respectively) (Supplementary Data 1A). The sh-NRP-1 stable clones were performed as described before (Vintonenko et al, 2011).

Intracardiac experimental colonisation model. All animal experiments were carried out with the local and IUH Saint Louis ethics committees' approval. The ethical guidelines that were followed meet the standards required by the UKCCCR guidelines (Workman et al, 2010). Female nude mice (8-10 weeks old, Janvier, Legenest St Ile, France) were anaesthetised by intraperitoneally (i.p.) injection of $120 \mathrm{mg} \mathrm{kg}^{-1}$ ketamine and $6 \mathrm{mg} \mathrm{kg}^{-1}$ xylazine (2\% Rompun, Bayer SAS, Lyon, France), and by exposure to $1-3 \%$ isoflurane on subsequent imaging days. Intracardiac injection was performed as previously described (Jenkins et al, 2005; Abdelkarim et al, 2009). On day 0, bioluminescent tumour cells $\left(10^{5}\right.$ in $100 \mu \mathrm{l}$ PBS $)$ were injected into the left ventricle of the heart. D-luciferin (150 $\mathrm{mg} \mathrm{kg}^{-1}$ ) was injected i.p. and the animals 
were transferred to a light-tight chamber for whole-body optical imaging, with the acquisition of both dorsal and ventral views with an IVIS Imaging System (Xenogen) and an intensified chargecoupled device camera, over a period of $5 \mathrm{~min}$ (Abdelkarim et al, 2009). Successful intracardiac injection was indicated on day 0 by systemic bioluminescence throughout the animal. During the whole experiment, colonisation sites were identified by persistent bioluminescence signal in the experiment time span using bioluminescence IVIS Imaging System (Xenogen). Both dorsal and ventral sites were observed. Colonised sites were determined by the presence of bioluminescence signal on the acquisition images without limitation of size. Colonisation was monitored in vivo, at least twice a week, after a period of 10 weeks. Killing was performed at the end of the study, or before in accordance with ethical guidelines, in particular weight loss (Workman et al, 2010). As bioluminescent regions corresponded to the presence of tumour cells, we excised organs from the whole mice in each positive bioluminescent area. These organs were immediately visualised by ex vivo imaging (IVISTM Imaging System) to verify the persistence of bioluminescent signal and to avoid confusion in localisation (between thorax bone and lung for example); further, histological examination was performed to determine the presence of tumour cells. In each case, when a bioluminescent signal was detected in an organ, tumour cells were detected by histological observation. For all mice, all lung lobes were taken out.

Histopathology. Tissues were fixed in $4 \%$ paraformaldehyde overnight and embedded in paraffin (Hervé et al, 2008). Supplementary decalcification was applied for the bone. Each sample was cut into $5-\mu \mathrm{m}$ sections and stained with haematoxylin and eosin (H\&E). All lung lobes were analysed for the presence of tumour cells.

Immunocytochemistry using a specific smooth muscle (SM)alpha actin antibody (A2547, Sigma, St Quentin Flavier, France; $1 / 400$ ) was performed on the mice's lung lobes in which the presence of tumour cells was detected by bioluminescence signal and confirmed by $\mathrm{H} \& \mathrm{E}$. (All these correlations were not shown and ex vivo images were in Supplementary data 2C.) For each animal, two sections of lungs positive for tumour cell were immunostained with SM-alpha actin antibody. The quantification of positively stained cells was based on a grid-supported manual count. The results were expressed as the following percentage: (number of SM-alpha positive cells/total tumour cells in the lung) $\times 100$.

Viability assay. Cells were plated on 96 -well plates $\left(5 \times 10^{3}\right.$ per well) and grown in DMEM-10\% FBS for 3 days. The growth of bioluminescent cells was measured using the XTT assay (Roche Diagnostics), as previously described (Hervé et al, 2008). Absorbance was recorded at $450 \mathrm{~nm}$, with a reference at $620 \mathrm{~nm}$ serving as a blank, with a microplate reader. The experiments were performed three times, each in triplicate.

Invasion assay. Cell migration experiments were performed in Boyden invasion chambers equipped with $8-\mu \mathrm{m}$ pores filters and coated with Matrigel (Falcon, MA, USA). Equal volumes $(0.5 \mathrm{ml}$ per chamber) of cell suspension $\left(3 \times 10^{4}\right.$ cells per $\left.\mathrm{ml}\right)$ were used to seed the Matrigel invasion chambers, which were incubated at $37^{\circ} \mathrm{C}$ for $16 \mathrm{~h}$. We used $10 \%$ FCS in DMEM as a chemoattractant. After $16 \mathrm{~h}$ of incubation, cells in the upper chambers that had not migrated were removed by wiping with a cotton swab. The cells on the lower surface of the filter were fixed, stained with crystal violet and counted (Abdelkarim et al, 2009). The number of cells invading the Matrigel was determined by counting cells from 10 microscopic fields. Experiments were performed in triplicate.

Apoptosis/cell death detection. MDA-MB-231 cells transfected with a VEGF isoform or control construct were starved for $72 \mathrm{~h}$ in a serum-depleted medium (DMEM $1 \mathrm{gl}^{-1} \mathrm{D}$-glucose, $0.5 \% \mathrm{FBS}$ ). Adherent cells were rinsed with $\mathrm{PBS}$ and subjected to double staining with fluorescein isothiocyanate-labelled annexin $\mathrm{V}$ and propidium iodide (PI), according to the manufacturer's instructions for the Annexin $\mathrm{V}$ apoptosis assay (Beckman Coulter, Fullerton CA, USA). Annexin V detects a phosphatidylserine translocation specific to early (API) and late (APII) stages of apoptosis, whereas APII and the first stage of necrosis are revealed by the incorporation of PI, which enters the cells when the cell membrane is damaged. Immediate analysis was carried out in a FACScan (Becton Dickinson, Sunnyvale, CA, USA) on 10000 cells gated on the basis of forward and side scatter. Cell debris was excluded from the analysis on the basis of scatter signals. The position of the quadrant gate was set, so that the principal populations $(>70 \%)$ of relevant untreated cells were viable (Annexin $\mathrm{V}^{-} / \mathrm{PI}^{-}$).

Isolation of cancer cells from mouse lungs. Human metastases were isolated from the lungs with collagenase I and cultured in DMEM (Gibco, St Aubin, France) supplemented with 10\% FBS, 1\% penicillin-streptomycin, $1 \%$ sodium pyruvate supplemented with geneticin G418 ( $0.5 \mathrm{mg} \mathrm{ml}^{-1}$; Gibco) in dishes coated with $0.5 \%$ gelatin. The human metastases were selected according to their resistance to geneticin used at $1 \mathrm{mg} \mathrm{ml}^{-1}$. All cell lines were cultured in a humidified atmosphere containing 5\% carbon dioxide, at $37^{\circ} \mathrm{C}$, with a total medium replacement every other day.

RT-Q-PCR analysis. Reverse transcription of $1 \mu \mathrm{g}$ of total RNA from each sample was performed with 100 units of Superscript II RNase $\mathrm{H}$ reverse transcriptase (Invitrogen, CergyPontoise, France) and $3 \mu \mathrm{M}$ random hexamers (Pharmacia, Uppsala, Sweden). Differences in gene expression were assessed by calculating the fold change in gene expression with real-time quantitative RT-PCR (ABI Prism 7900 sequence Detection System, PerkinElmer Applied Biosystems, Foster City, SA, USA), with the TBP gene (TATA box-binding protein) as an endogenous RNA control.

Transcriptomic analyses. Whole-genome expression profiling of MDA-MB 231 overexpressing VEGF189 (V189), MDA-MB 231 overexpressing VEGF165 (V165) or control cells (cV) was carried out with AffymetrixGeneChip Human Gene 1.0 ST arrays. Similarly, MDA-MB-231-derived lung metastases obtained after the intracardiac injection of V165, V189 and $\mathrm{cV}$ clones, respectively, V165M, V189M or control clones (cVM) were also analysed with AffymetrixGeneChip Human Gene 1.0 ST arrays. These microarrays have 764885 features corresponding to 28869 known unique human genes. In all those clones, we isolated total RNA from 18 cell cultures (four biological replicates corresponding to four different passages of V189, V165 and cV, and two biological replicates corresponding to two different passages of $189 \mathrm{M}, 165 \mathrm{M}$ and $\mathrm{cM}$ clones) with the RNeasy mini kit (Qiagen, Valencia, CA, USA), by direct cell lysis in 10-cm culture dishes containing $600 \mu \mathrm{l}$ RLT Buffer according to the manufacturer's instructions. Total RNA was quantified with a Nanodrop ND-1000 spectrophotometer (Thermo Fisher Scientific, Hudson, NH, USA) and its quality was assessed by running the eukaryotic total RNA nano assay on a Bioanalyzer 2100 (Agilent Technologies, Chandler, AZ, USA) with the Agilent RNA 6000 Nano Kit. Probes (300 ng of total RNA) were prepared for hybridisation to AffymetrixGeneChip Human Gene 1.0 ST arrays (Affimetrix, Cleveland, OH, USA), according to the manufacturer's instructions.

Data analyses. The scanned raw data were processed with the apt-probe-set summarise program from Affymetrix Power Tools (v1.10.2) for background correction and normalisation. The RMA (Robust Multichip Analysis) algorithm (Irizarry et al, 2003), with full quintile normalisation, was applied, with array design library files V1 release 4, and normalised values were expressed on a log base 2 scale. Transcripts and genes were annotated with the Affymetrix release 29 annotation file based on the human genome version 18 assembly. Data were analysed with the R Bioconductor 
LIMMA package (Smyth, 2005). The microarray data have been deposited in the NCBI Gene Expression Omnibus (Edgar et al, 2002) and are accessible through the GEO Series accession number GSE37911 (http://www.ncbi.nlm.nih.gov/geo/query/acc.cgi?acc=G SE37911). Probe sets corresponding to control genes or with a lowintensity signal (median $\log 2$ of intensity $<4$ ) or low variability were not considered for further analyses. Only genes with a false discovery rate $<0.05$ and a log fold change value $\geqslant \pm 1$ in paired comparison between treatments and their corresponding controls were considered to be differentially regulated. Data for V189 and V165 were compared by calculating the difference in log fold change for each gene (log fold change in the V165 data set - log fold change in the V189 data set). Only genes with a differential log fold change $\geqslant \pm 1$ and a false discovery rate $<0.05$ were considered to be differentially regulated.

Patients and samples. Human breast tumours were excised from women at the Institut Curie-Centre René Huguenin in St Cloud, France. All patients who entered this institution before 2007 were informed that their tumour samples might be used for scientific purposes and had the opportunity to decline. Since 2007, patients entering the institution have given their approval also by signed informed consent. This study was approved by the local ethics committee (Breast Group of the René Huguenin Hospital). We investigated the relationships between mRNA levels for genes of interest and metastasis-free survival by analysing 120 (60 which metastasised to distant sites and 60 which did not) human breast tumours excised from women at Institut Curie-Centre René Huguenin (St Cloud, France). This study was approved by the local ethics committee (Breast Group of the René Huguenin Hospital). Samples containing $>70 \%$ tumour cells were considered suitable for this study. Immediately after surgery, the tumour samples were frozen in liquid nitrogen, in which they were stored until RNA extraction. The characteristics of the patients are shown in Table 1. We determined the oestrogen receptor, progesterone receptor and ERBB2 status of the tumours at the protein level, by biochemical methods (enzymatic immunoassay), with confirmation by real-time PCR. The malignancy of infiltrating carcinomas was scored according to Scarff Bloom and Richardson's histoprognostic system (Bloom and Richardson, 1957).

In silico analyses. We identified genes involved in breast carcinogenesis by analysing genes expressed differentially in the V165 and V189 clones (V165 vs V189) or in 165M and 189M lung metastases (165M vs 189M), on Oncomine (www.oncomine.org), with the Richardson breast 2 cancer data set in particular. This data set corresponds to 40 ductal breast carcinomas and seven normal breast samples that were analysed on Affymetrix U133 Plus 2.0 microarrays (Richardson et al, 2006) (http://www.ncbi.nlm.nih. gov/geo/ query/acc.cgi?acc=GSE3744s). For each gene, we checked the expression level (fold change) and the corresponding $P$-value $(P<0.05$ considered significant $)$ in the Richardson breast 2 data set. We took into account only the genes considered to be significantly misregulated. We then analysed those misregulated genes with BRB-ArrayTools, version $3.3 \beta 3$ (Rockville, MD, USA), developed by Dr R. Simon and Dr A. Peng Lam on a series of human breast tumours $(n=344)$ described in detail elsewhere (Wang et al, 2005). We used a filter to refine the metastasis-related gene set. The Cox proportional hazards model and Wald statistics were used for univariate analysis. Metastasis-free survival and $P$-values $<0.05$ were considered significant in each univariate test. Only significantly misregulated genes were taken into account in subsequent real-time PCR analysis.

Statistical analyses. The graphs show the means and the standard errors of the means. We used a suitable two-way ANOVA multiple comparison test including the Kruskal-Wallis test followed by the Dunn post-test. The statistical analyses were performed using
Table 1. Characteristics of the 120 human breast tumours

\begin{tabular}{|l|c|c|c|}
\hline & $\begin{array}{c}\text { Number of } \\
\text { patients (\%) }\end{array}$ & $\begin{array}{c}\text { Number of } \\
\text { relapse (\%) }\end{array}$ & $P_{\text {-value }}$ \\
\hline Total & $120(100.0)$ & $60(50)$ & \\
\hline Age & $20(16.7)$ & $11(55)$ & $0.60(N S)$ \\
\hline 50 & $100(83.3)$ & $49(49)$ &
\end{tabular}

SBR histological grade ${ }^{\mathrm{b}, \mathrm{c}}$

\begin{tabular}{|l|c|c|c|}
\hline I & $14(11.9)$ & $5(35.7)$ & 0.14 (NS) \\
II & $58(49.2)$ & $29(50)$ & \\
III & $46(39.0)$ & $25(54.3)$ & \\
\hline
\end{tabular}

Lymph node status $^{\text {d }}$

\begin{tabular}{|l|l|l|l|}
\hline 0 & $30(25.2)$ & $14(46.7)$ & 0.48 (NS) \\
$1-3$ & $62(52.1)$ & $30(48.4)$ & \\
$>3$ & $27(22.7)$ & $16(59.3)$ & \\
\hline
\end{tabular}

Macroscopic tumour size ${ }^{c}$

\begin{tabular}{|l|l|l|l|}
\hline $\begin{array}{l}\leqslant \\
>25 \mathrm{~mm}\end{array}$ & $56(47.5)$ & $22(39.3)$ & 0.013 \\
\hline
\end{tabular}

ER status

\begin{tabular}{|l|l|l|l|}
\hline Negative & $36(30)$ & $21(58.3)$ & 0.0019 \\
Positive & $84(70)$ & $39(46.4)$ & \\
\hline
\end{tabular}

\begin{tabular}{|l|l|l|l|}
\hline Positive & $84(70)$ & $39(46.4)$ & \multicolumn{1}{l}{} \\
\hline Pegative & $56(46.7)$ & $31(55.4)$ & 0.041 \\
Positive & $64(53.3)$ & $29(45.3)$ &
\end{tabular}

\begin{tabular}{|l|l|l|l|}
\hline \multicolumn{5}{|l|}{ ERBB2 status } \\
\hline Negative & $98(81.7)$ & $49(50)$ & 0.72 (NS) \\
Positive & $22(18.3)$ & $11(50)$ & \\
\hline Molecular subtypes &
\end{tabular}

\section{Molecular subtypes}

\begin{tabular}{|l|l|r|r|}
\hline $\mathrm{RH}-$ ERBB2 - & $25(20.8)$ & $15(60)$ & 0.016 \\
$\mathrm{RH}-$ ERBB2 + & $11(9.2)$ & $6(54.5)$ & \\
$\mathrm{RH}+$ ERBB2 - & $73(60.8)$ & $34(46.6)$ & \\
$\mathrm{RH}+$ ERBB2 + & $11(9.2)$ & $5(45.5)$ & \\
\hline
\end{tabular}

\begin{tabular}{|c|c|c|c|}
\hline \multicolumn{4}{|c|}{ PIK3CA mutation status } \\
\hline Wild type & $79(65.8)$ & 42 (53.2) & 0.070 (NS) \\
\hline Mutated & $41(34.2)$ & $18(43.9)$ & \\
\hline \multicolumn{4}{|c|}{$\begin{array}{l}\text { Abbreaviation: NS=non significant. } \\
\text { a } \\
\text { sog-rank: survival distributions were estimated by the Kaplan-Meier method, and the } \\
\text { b }{ }_{\text {Scarff Bloom Richardson classification. }} \\
c_{\text {Information available for } 118 \text { patients. }} \\
d_{\text {Information available for } 119 \text { patients. }} \\
\text { Bold values: } P<0.05 \text {. }\end{array}$} \\
\hline
\end{tabular}

GraphPad Prism 5.01 software (La Jolla, CA, USA). ${ }^{\star} P<0.05$. To analyse the prognostic value of the genes tested by RT-PCR in the series of 120 human breast tumours, the optimal cutoff for each gene was determined by calculating the area under the curve for a comparison of tumours without metastases $(n=60)$ and tumours giving rise to metastases $(n=60)$. We used these optimal cutoffs to determine survival for each gene. Survival distributions were estimated by the Kaplan-Meier method, and the significance of differences in survival rate was assessed in log rank tests. The relationships between mRNA levels for the various target genes were investigated in Spearman's rank correlation tests (assessing the correlation between two quantitative parameters). Differences were considered significant if $P<0.05$.

\section{RESULTS}

VEGF189 overexpression reduced the number of mice with MDA-MB-231 colonisation sites delaying the lung and bone tumour uptakes. Bioluminescent breast cancer cell lines can be used for a rapid and sensitive in vivo detection of cell dissemination throughout the body of immune-deficient mice 
(Supplementary Data 1A and B; Jenkins et al, 2005; Minn et al, 2005; Abdelkarim et al, 2009). Bioluminescent V189-B and V165-B clones and $\mathrm{cV}$-B control cells were injected into the left heart ventricle of female nude mice ( $n=10$ per group). Fourteen days later, the bioluminescent tumour cells were clearly detectable and their numbers increased over a period of 6-10 weeks. In contrast to $\mathrm{cV}$ and V165 clones, V189 resulted in a significantly longer time for tumour colonies to appear in the mice (Figure 1A, left panel).
The number of colonisation sites appeared in a smaller proportion after the injection of VEGF189-overexpressing cells than after injection of the controls or VEGF165-overexpressing cells (V189-B vs cV orV165-B) (Figure 1A; right panel; Supplementary Data 2A). After 16 days, only $10 \%$ of the mice receiving injections of the V189-B clone had developed tumour colonised sites, against 50\% of the mice receiving injections of $\mathrm{cV}-\mathrm{B}$ and V165-B cells (Figure 1A, left panel). After 38 days, almost all the mice
A

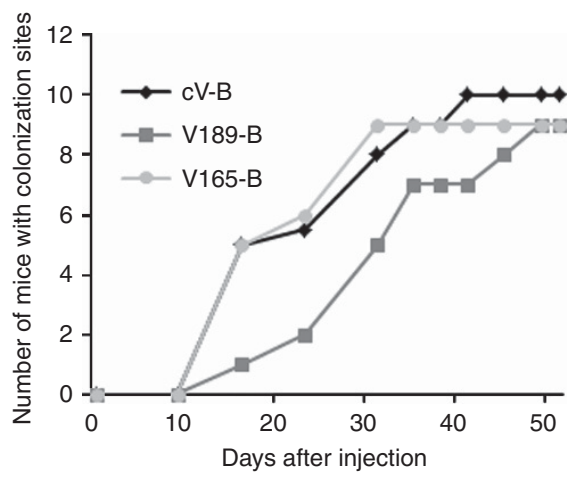

B

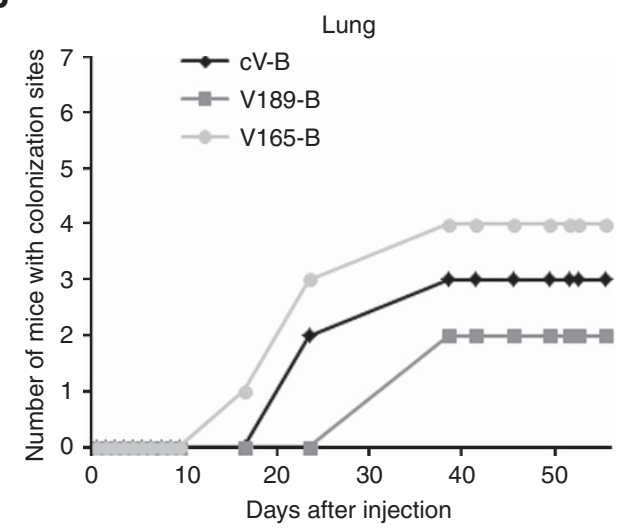

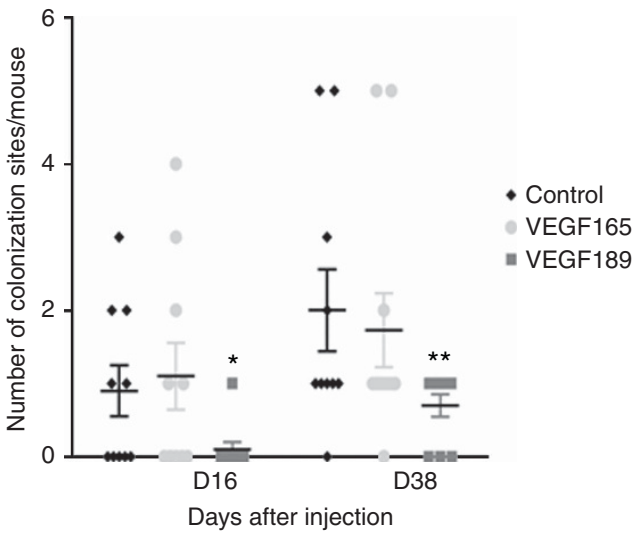

Bone

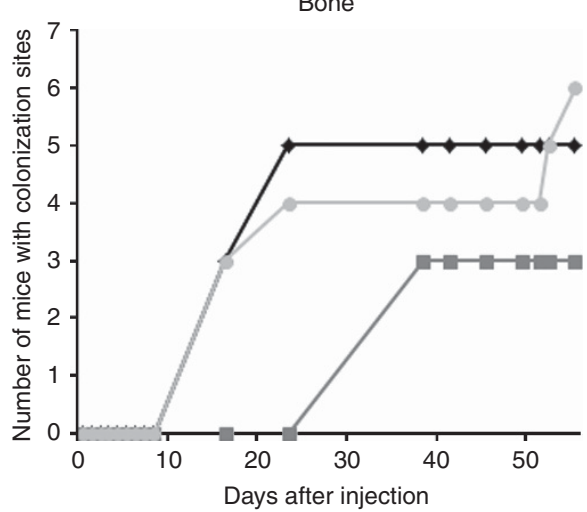

C
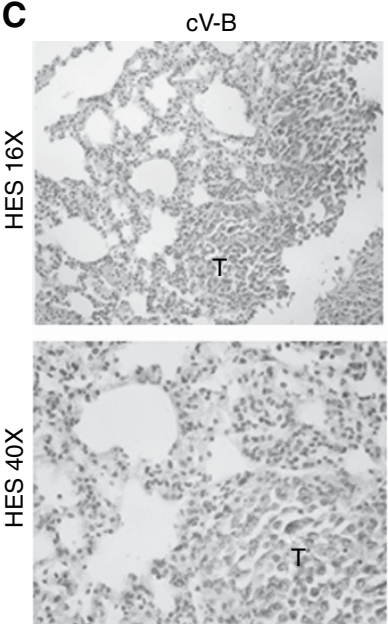
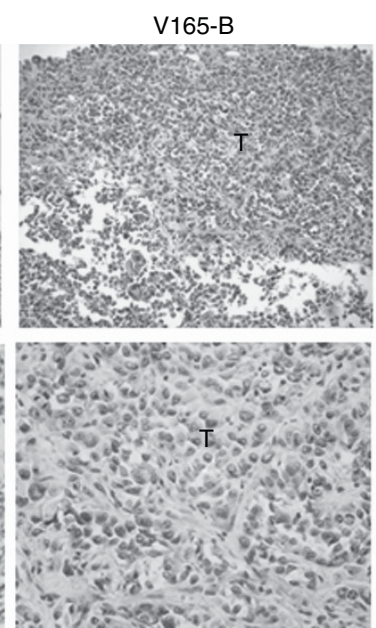

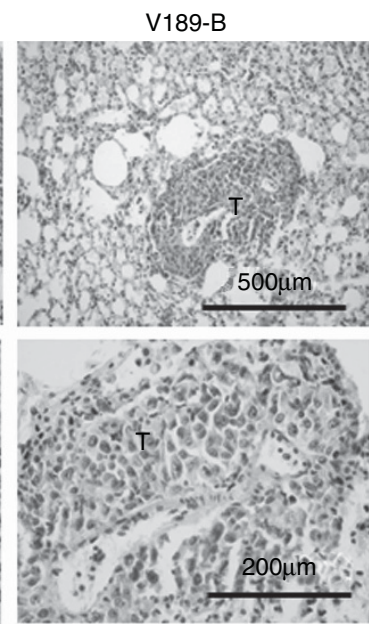

Figure 1. VEGF189 overexpression in MDA-MB-231 breast cancer cells decreases the number of mice with colonisation sites in vivo and delays colonisation in the bone and lungs. (A) Tumour formation for the various bioluminescent clones injected into mice $(n=10)$. Left panel: number of mice with colonisation sites. Right panel: number of colonisation sites per mouse. (B) Number of mice with colonisation present in the bone and lungs after injection with the various clones (V165, V189 and cV). At the indicated times, the total numbers of mice with metastasis in the bone (legs) and lungs were counted in each group. ${ }^{*} P_{\mathrm{V} 189} v s P_{\mathrm{C}-\mathrm{V}}$ and $P_{\mathrm{V} 165}<0.05$ and ${ }^{*}{ }^{*} P_{\mathrm{V} 189} v s P_{\mathrm{C}-\mathrm{V}}<0.05$. (C) Haematoxylin- and eosin-stained sections of breast cancer tumour in lung tissue ( $T$ ). Different patterns of colonisation are shown: more or less invasive (middle and right, respectively). Original objective magnification, $\times 16$ (top), $\times 40$ (bottom), scale bars are 500 and $200 \mu \mathrm{m}$, respectively. 
(90-100\%) receiving cV-B or V165-B clones injections had developed tumour sites, vs $70 \%$ of the mice injected with V189-B clones (Figure 1A, left). V189-B-injected mice had a significantly smaller total number of colonisation sites than those injected with the V165-B and cV-B clones after 16 days $(P=0.04)$ and this difference is lower and only significant for V189 vs cV-B cells $(P=0.037)$ after 38 days of the time course, underlying the delaying effect of VEGF189 overexpression (Figure 1A, right panel). Moreover, the lower colonisation observed with the V189 clone was associated with greater mouse survival (Supplementary Data 2B).

The intracardiac injection of V189-B cells into nude mice resulted in fewer mice with lung or bone metastasis, than observed with injection of V165-B and cV-B control cells (Figure 1B; left and right panels, respectively). In both cases (bone and lung), we observed a delay in tumour uptake with V189-B cells (25 days), compared with V165-B cells (9 days) and cV-B controls (18 days). Histological examination of the lungs excised from the mice confirmed cancer cell invasion and showed heterogeneity in the lung parenchyma between VEGF189-B, V165-B and cV-B clones (Figure 1C). The presence of tumour burden was correlated to the presence of bioluminescence signal but no significant differences were observed between the mean of ROI quantification in each group (data not shown).

We observed that bone colonisation in the mice also occurred later with V189-B clones (25 days) than with V165-B (9 days) or cV-B clones (9 days) (Figure $1 \mathrm{~B}$ ). Salivary and adrenal glands (kidney) were also colonisation sites in addition to the lungs, bone and brain but to a lesser extent (Supplementary Figure 2C). The number and pattern of tumour formation in the brain differed from that in the lungs and bone (data not shown). V189-B clones induced fewer mice with colonisation in the brain before day 32 than V165-B and cV-B cells (data not shown), but this difference subsequently disappeared and was not observed at day 40 .

VEGF as an autocrine factor and regulation via NRP-1. We previously demonstrated that VEGF can affect non-angiogenic aspects of tumour cell progression, through autocrine loop acting on tumour cells (Bachelder et al, 2001, 2003; Lee et al, 2007; Hervé et al, 2008; Vintonenko et al, 2011; Perrot-Applanat and Di Benedetto, 2012). VEGF165 has been shown to increase the invasiveness and survival of breast cancer cells (Orimo et al, 2005, Oskarsson et al, 2011). We further analysed the invasiveness of VEGF189-overexpressing clones, in the Matrigel invasion chamber assays. As NRP-1 was demonstrated to interact with VEGF189 and to modulate VEGF effect on cell survival (Vintonenko et al, 2011), we performed the silencing of NRP-1 to investigate the modulation of invasion induced by VEGF 189 and 165 isoforms (Figure 2A). The number of V189-overexpressing MDA-MB-231 cells invading the Matrigel was significantly decreased by half compared with the more invasive control cV-B and V165-B clones (Figure 2A). We observed that silencing the expression of NRP-1 had no effect on VEGF165-B clones or the cV-B control invasion, whereas it reversed the decrease of VEGF189-expressing cell invasion. In addition, the clones were analysed in cell culture in limiting conditions (0.5\% FBS and $1 \mathrm{gl}^{-\mathrm{i}}$ glucose) by FACS analysis (Figure 2B and C). As expected, the number of apoptotic V189-B cells $\left(\mathrm{AnnV}^{+} / \mathrm{PI}\right.$ and $\left.\mathrm{AnnV} \mathrm{V}^{+} / \mathrm{PI}^{+}\right)$was increased about two-fold as compared with $\mathrm{cV}-\mathrm{B}$ and V165-B cells (Figure 2B and C). Thus, VEGF189 may act as an autocrine factor via NRP-1, resulting in lower levels of cell invasion than with the VEGF165 isoform.

VEGF189 and VEGF165 lung metastasis exhibit different stromal compartment. As the presence of SM-alpha actinpositive cells is strongly associated with tumour aggressiveness (Orimo et al, 2005), we performed immunostaining with the SMalpha actin antibody to detect myofibroblasts in the compartment of lungs positive for V165-B and V189-B tumour cells (Figure 3A).
The percentage of positive cells was higher in the lungs colonised by V165-B cells than in ones colonised by V189-B or cV-B cells (Figure 3A). The overexpression of VEGF165 and VEGF189 in isolated lungs positive for tumour cells (called V165, V189 and cV, respectively) was confirmed by RT-PCR (Figure 3C). The correlation between the expression evaluation by RT-PCR of the VEGF isoforms and their protein levels was previously demonstrated (Hervé et al, 2008). Besides, V189 cells also expressed significantly lower levels of MMP1mRNA than V165 cells (Figure 3C). We further investigated the expression in those clones of tenascin-C (TNC), a well-known marker of stroma associated with epithelial malignancy (Mackie et al, 1987; Dandachi et al, 2001). V189 cells expressed significantly lower levels of TNC mRNA than $\mathrm{cV}$ and V165 cells (Figure 3D).

Transcriptomic profiles of the V189 vs the V165 cell line and of the $189 \mathrm{M} v$ s the $165 \mathrm{M}$ lung metastatic cell line. We compared the transcriptomic profiles of the V165 and V189 cell lines (Supplementary Data S4). We identified a subset of 149 genes with significantly different expression levels in the two cell lines (V165 vs V189) $(P<0.05$ and $|\log \mathrm{FC}|>1)$ (Supplementary Data S4). We reduced the number of genes for further analysis, by comparing our 149 deregulated genes with a list of human genes known to be specifically involved in mammary carcinogenesis. We used the Richardson breast 2 database (oncomine.org), which compared the expression of 19514 human genes between 40 breast tumours and seven normal breast tissue samples. We found that 36 genes expressed differentially between V165 and V189 cells (V165 vs V189 list) were also included in the Richardson breast 2 database (Figure 4A). We then analysed the expression profiles of the 36 genes identified with BRB-ArrayTools and a metastasis potential event selection filter, and identified 11 genes expressed significantly (Figure 4A).

As described above, animals developed distant lung colonisation after intracardiac injection of the V165, V189 and cV clones. We applied the same protocol to these lung metastatic cell lines. We first identified a subset of 150 genes displaying significant differential expression between $165 \mathrm{M}$ and $189 \mathrm{M}$ cells $(165 \mathrm{M}$ vs $189 \mathrm{M})(P<0.05$ and $|\log \mathrm{FC}|>1$ ) (Figure 4B; Supplementary Data S5). After the specific selection of genes involved in metastatic processes, from the Richardson breast 2 database and BRB ArrayTools, respectively (Figure 4B), we identified seven genes expressed significantly (Figure 4B).

We thus identified a subset of 18 genes both regulated differentially between V165 (or 165M) and V189 (or 189M) and involved in breast cancer and metastasis potential (Figures $4 \mathrm{~A}$ and B).

Overexpression of 18 selected genes in 120 human breast cancers. We further analysed the expression of these 18 genes and four other genes as controls (TNC, VEGFA, VEGF165 and VEGF189) in a series of 120 human breast tumours (Table 1), which we compared with 10 normal breast tissue samples by quantitative RT-PCR (Table 2). Values of 3 (or more) were considered to indicate marked overexpression, and values of 0.33 (or less) were considered to indicate marked underexpression. Overexpression in breast tumours was the change in expression profile most frequently found in the 22 selected genes compared with normal tissues (Table 2). Changes in gene expression were detected in 13 of the 22 genes. We found that 13 of the 22 genes were frequently overexpressed in breast tumours compared with normal tissues ( $\%$ overexpression $>10 \%$ ), none of these genes was exclusively underexpressed in breast tumours (\% underexpression $>10 \%$ ) and 2 of these 18 genes (i.e., HRASLS and TNC) were overexpressed in some breast tumours and underexpressed in others (Table 2). A higher expression of VEGFA was also observed in breast tumours than in normal breast tissues $(27.5 \%$, median mRNA level: 1.82, range: $0.42-13.37$ ), and this was more marked for VEGF165 isoforms, which was associated with poor prognosis 
A

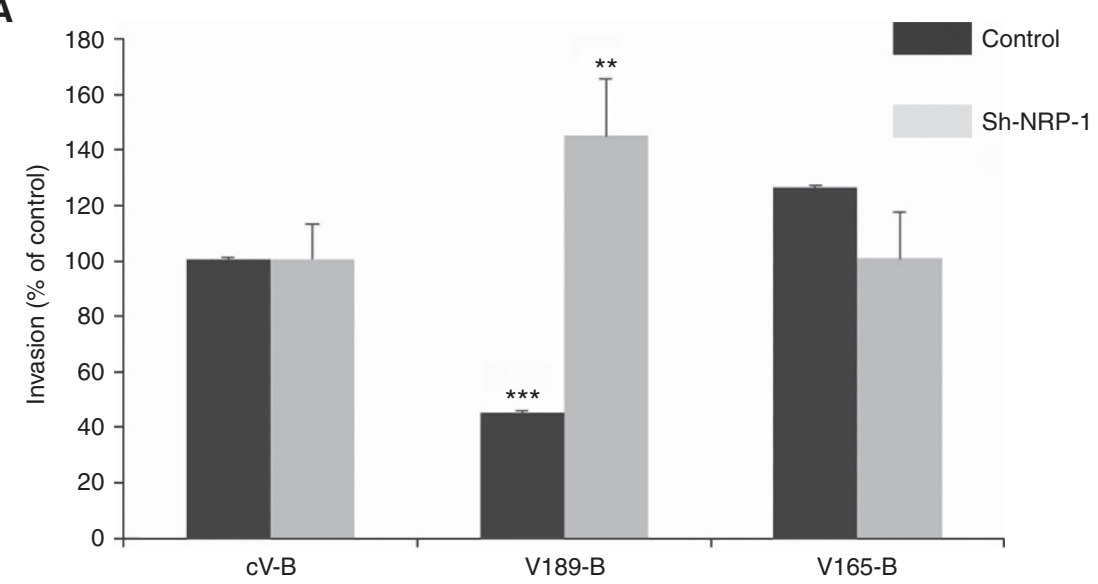

B
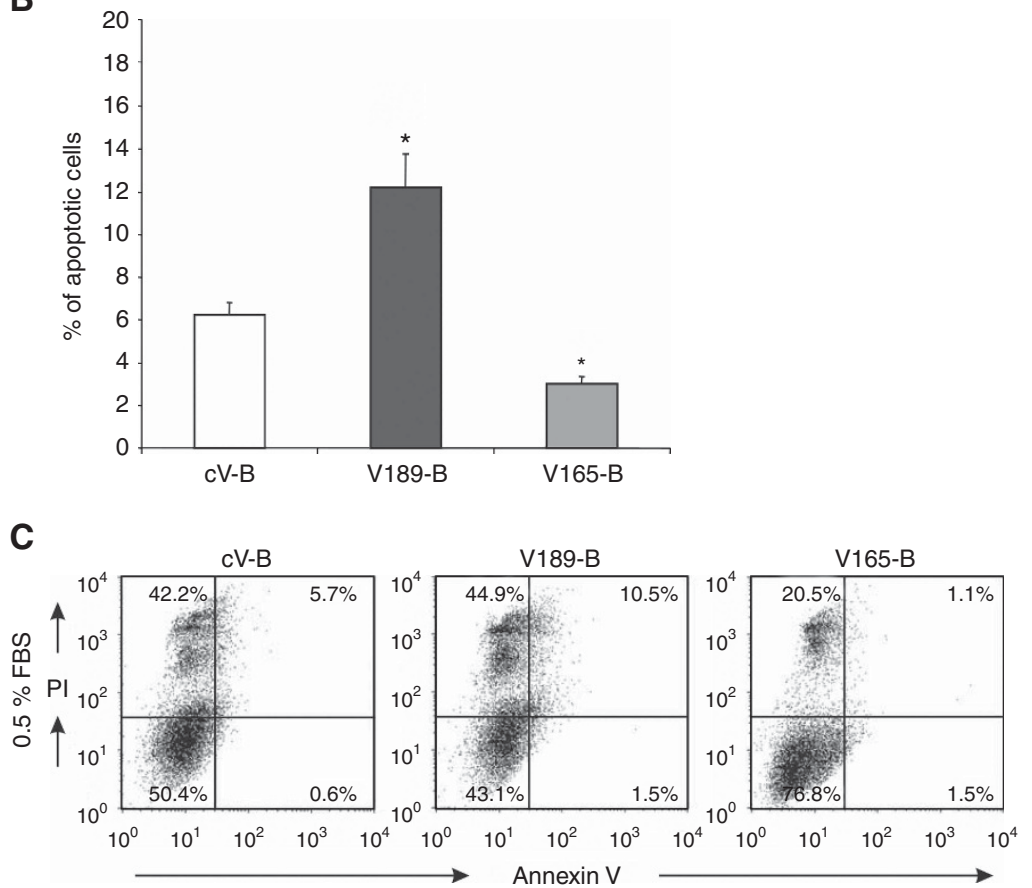

Figure 2. Lower invasive capacity and survival of V189-B clones in limiting serum conditions. (A) Histogram showing invasive capacities of cV-B, V189-B and V165-B clones and corresponding sh-NRP-1. Results are presented as \% invasion with respect to control cells, for which the value was set at $100 \%$ (means of four independent experiments \pm s.d.). ${ }^{* \star} P<0.05$. Significant values were shown for $V 189$ vs $\mathrm{CV}$ or $V 165$ vs $\mathrm{cV}$. ${ }^{\star \star} P<0.05$. Significant values were shown for V189 vs sh-NRP-1 of VEGF189 clones (B and C). Survival/apoptotic assay. (B) Histogram showing the mean \pm s.d. of apoptotic cells in the cV-B, V189-B and V165-B clones. ${ }^{*} P<0.01$. Significant values were shown for V189 and V165 vs cV. (C) Representative flow cytometry profiles for CV-B, V189-B and V165-B clones incubated in medium supplemented with 0.5\% FBS.

(26.7\%, median mRNA level: 1.89 , range: $0.35-16.43)$ than for VEGF189 isoforms (19.2\%, median mRNA level: 1.72, range: 0-15.54) (Table 2).

Relationship between overexpression of VEGF189 and the 18 selected genes. We then carried out Spearman's rank correlation tests to assess the extent to which the expression of the 19 genes identified $(18+$ TNC) was correlated with that of VEGF189/ VEGFA ratio (Figure 5A). We found a statistically negative correlation between the expression pattern of VEGF189 and the levels of expression of seven genes: CARS $(r=-0.381, P=0.000035)$, CPNE3 ( $r=-0.226, P=0.012)$, GINS2 $(r=-0.273, P=0.0027)$, GPRC5A $\quad(r=-0.219, \quad P=0.016), \quad H I S T 1 H 2 B K \quad(r=-0.338$, $P=0.00023), \quad T B C 1 D 8(r=-0.181, \quad P=0.045)$ and ZDHHC13 $(r=-0.270, P=0.003)$. Levels of VEGF165 expression were found to be correlated with the levels of expression of CTSL-1, GGH, HIST1H2BK, HRASLS, SFT2D2, TNC and MMP1 (data not shown).

We also tested the prognostic value of those seven genes correlated with expression pattern of VEGF189. As in our series of 120 human breast tumours (60 metastasising to distant sites and 60 displaying no metastasis; Table 1), we used a log rank test to determine the relationship between metastasis-free survival (MFS) and the mRNA levels for the seven selected genes. The differences in MFS between patients with low and high levels of expression of the selected genes were significant for two genes (Figure 5B). A significant difference in MFS between patients with low and high levels of GPRC5A, TBC1D8 and VEGF expression was observed ( $P=0.000012, P=0.009$ and $P=0.044$, respectively). Thus, high expression of GPRC5A, TBC1D8 and VEGFA expressions were strongly correlated with longer MFS (Figure $5 B$ ), suggesting that the overexpression of those genes in tumours is associated with 


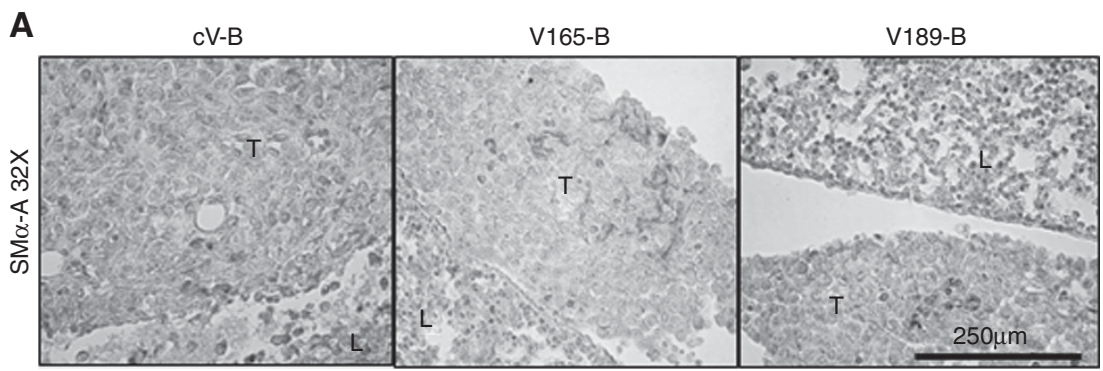

\section{B}

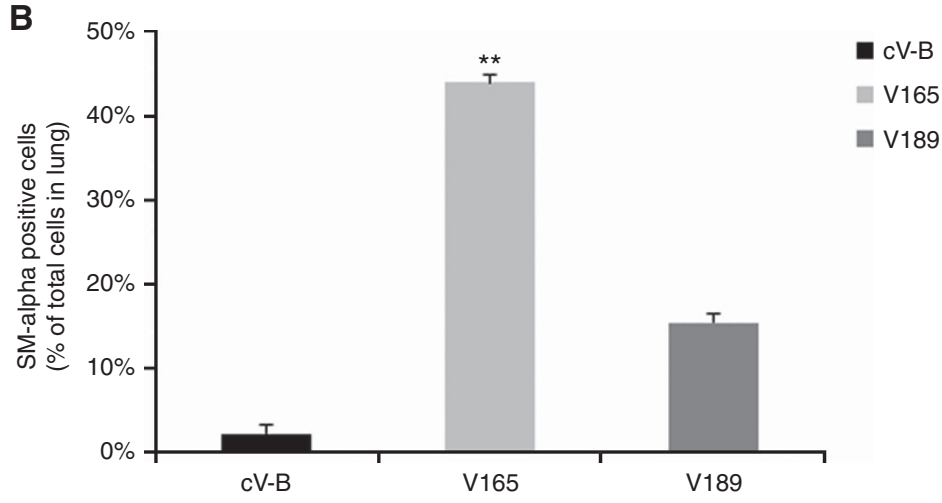

C

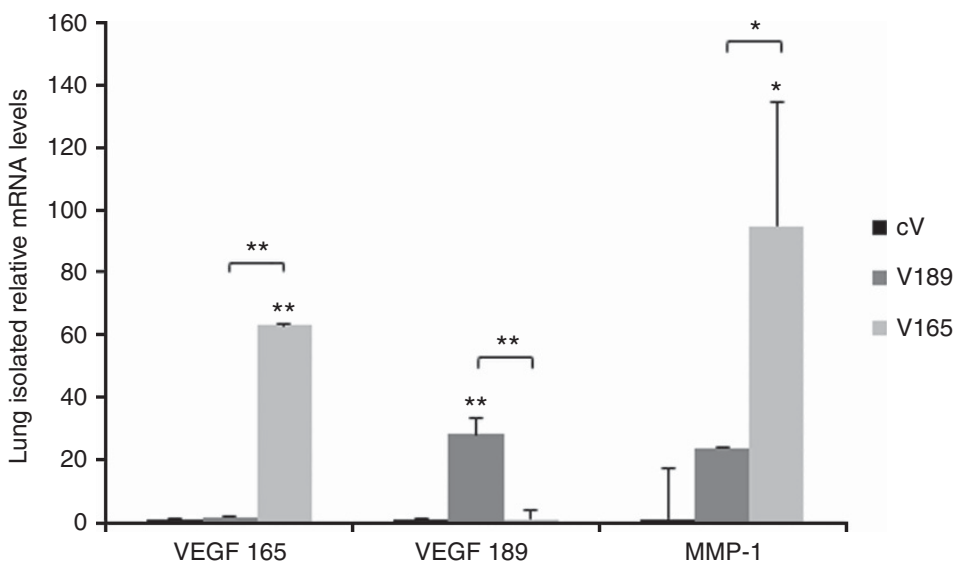

D

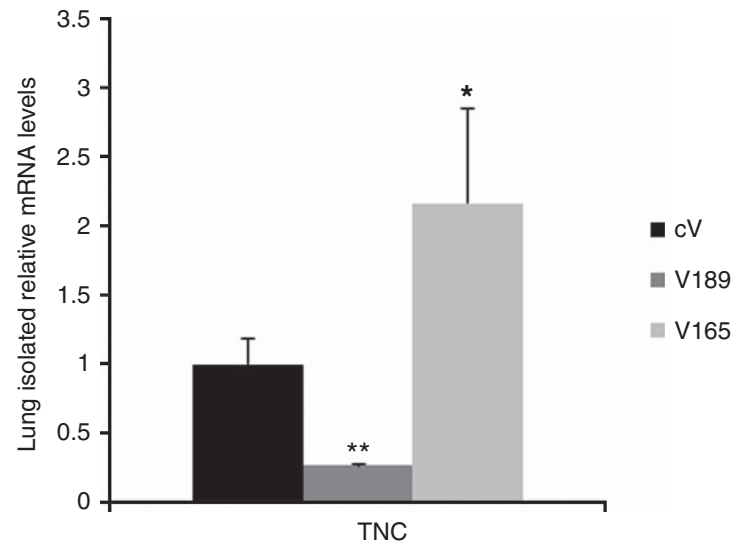

Figure 3. Stromal compartment and migration of gene expression. (A and B) Immunostaining (A) and quantification (B) for SM-alpha actin. For each animal, two sections per lung positive for tumour cells were immunostained with SM-alpha actin. Original objective magnification, $\times 32$; $T$ (tumor), L (Lung), ${ }^{\star *} P<0.01$, significant for V165, respectively, vs $\mathrm{CV}$. (C and D) RT-Q-PCR analyses of VEGF isoforms, MMP-1 (C) and TNC (D) in isolated CVM, V189M and V165M lung tumours cells. TBP was used as an internal control. The relative mRNA levels of each gene in the control are set to 1 , and values are expressed as means \pm s.e.m. ${ }^{\star} P<0.05,{ }^{\star \star} P<0.01$. Scale bar, $250 \mu \mathrm{m}$. 


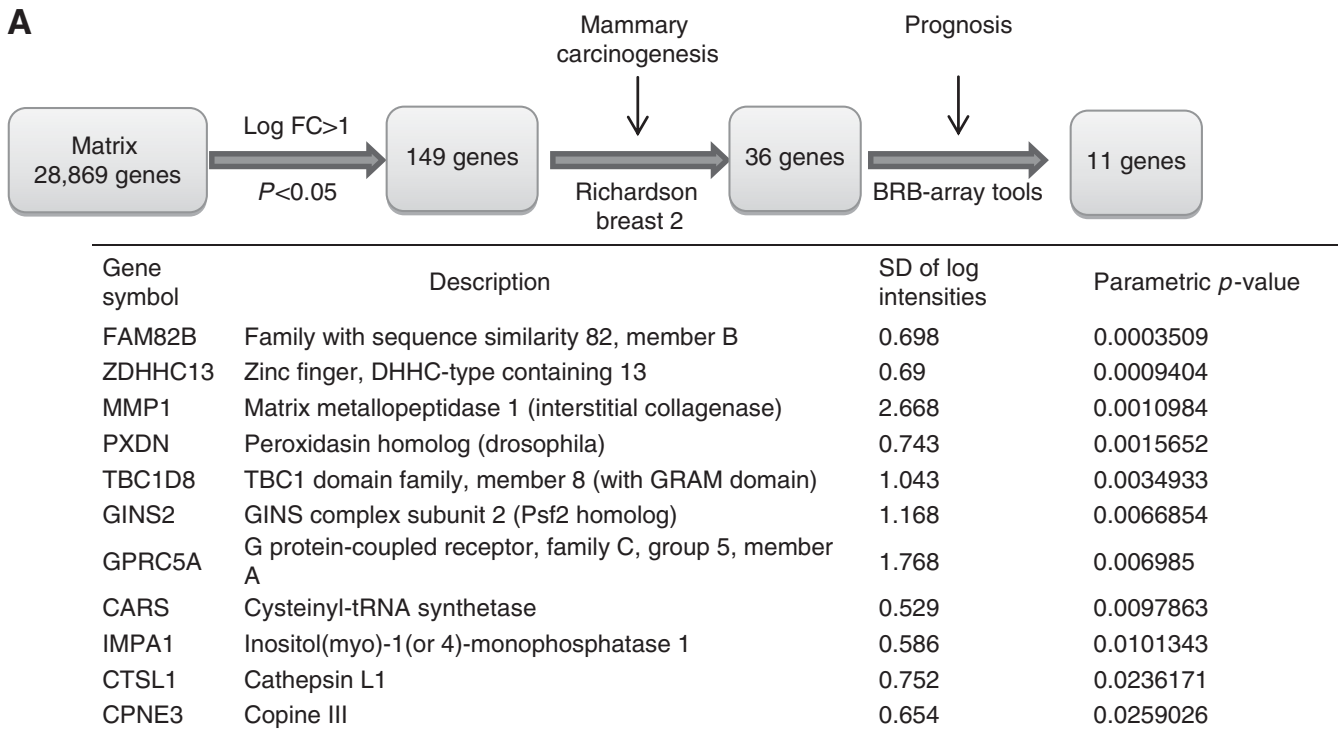

B

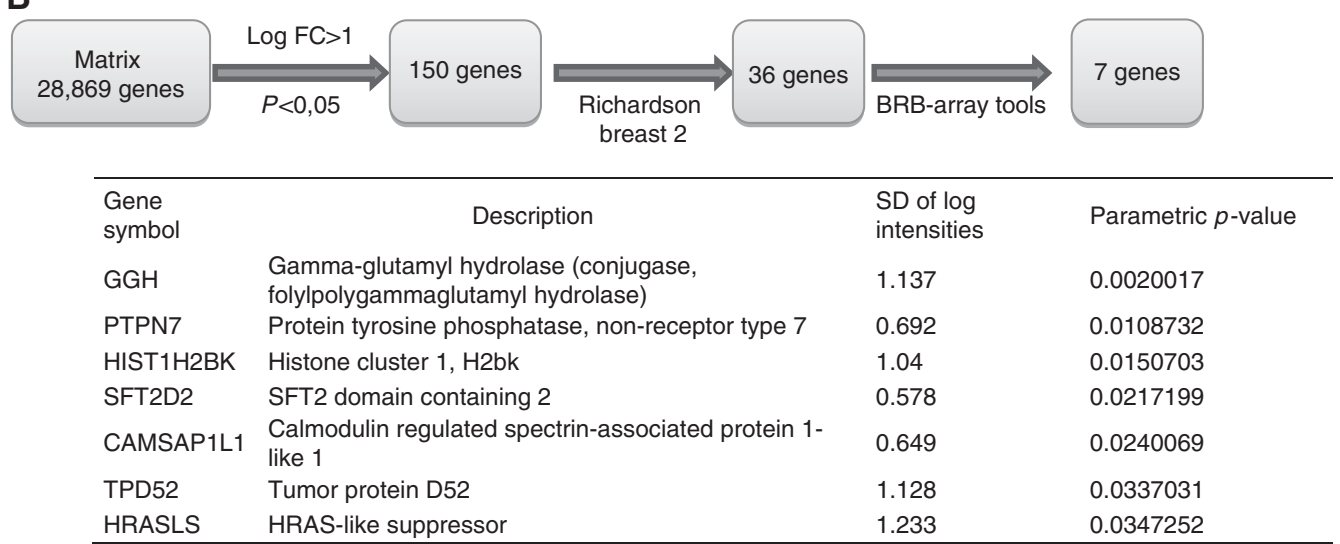

Figure 4. In silico analysis protocol. (A) In silico analysis comparing V165 with V189 as described in Materials and methods, and genes significantly expressed in the BRB data set and associated with invasive potential in the comparison of V165 with V189. (B) In silico analysis comparing V165M with $\mathrm{V} 189 \mathrm{M}$ as described in Materials and methods, and genes significantly expressed in the BRB data set and associated with invasive potential in the comparison of $\mathrm{V} 165 \mathrm{M}$ with $\mathrm{V} 189 \mathrm{M}$.

decreased metastasis potential with GPRC5A and TBC1D8 as opposed to high metastasis potential with VEGF165.

\section{DISCUSSION}

Transformed cells must acquire additional abilities to surmount the natural barriers against metastasis such as survival and migration/invasion. Thus, after entering the bloodstream, cancer cells must infiltrate, survive and then overtake new tissue. This study is the first to investigate the effects of VEGF isoforms in an important step involved in metastasis that is the colonisation of tissues. Previous results from our group for breast cancer (Hervé et al, 2008) and other cancers (Tokunaga et al, 1998; Yuan et al, 2001) have suggested that VEGF189 has an important role locally in aggressive tumours, especially by delaying tumour growth potential, invasion and migration of xenografted cells, and tumour angiogenesis (Perrot-Applanat and Di Benedetto, 2012). Here our results show that VEGF189 and VEGF165 differently influence the circulating tumour cell ability to colonise new tissues. The main colonisations occurred in the lungs and bone and to a lesser extent in other organs. V189-injected mice had less colonisation sites in vivo than mice receiving injections of the
V165 and cV clones (Figure 1), particularly in the bone and lungs. Differences in colonisation were less important when considering the brain, suggesting that the lungs or bone are the first sites colonised by breast tumour cells (Yoneda et al, 2001). Also, we observed that the intracardiac injection of MDA-MB-231 cells overexpressing VEGF induced colonisation of the lymph node, skeletal tissues, lungs and brain, with all clones, as described for breast cancer cells, including MDA-MB-231 (Minn et al, 2005; Steeg, 2006; El-Mabhouh et al, 2008; Bos et al, 2010; Price, 2010). Although injecting cells into the bloodstream is limited compared to the orthotopic model and that measurement of total tumour lung burden would have improved the study, our data as a whole suggest distinct effects of VEGF189 compared with VEGF165 isoforms on colonisation uptake, which could be associated with different effects on tumour cell functions.

Lungs with VEGF189 tumours were associated with significantly lower levels of $\alpha$ SMA-positive cells than VEGF165 tumours. Although we could not conclude on the stromal or tumour origin of this staining, lungs with VEGF189 cell colonisation expressed lower levels of TNC and MMP1 than those containing VEGF165 cells. Joan Massagué's laboratory recently showed that TNC is associated with aggressive lung metastasis as described before (Mackie et al, 1987; Oskarsson et al, 2011). Indeed, TNC enhances the expression of stem cell signalling components, thereby 
Table 2. Quantitative PCR analyses of the 22 genes of interest in 120 human breast tumours

\begin{tabular}{|c|c|c|c|c|c|c|}
\hline Genes & $\begin{array}{c}\text { Ct median of } \\
\text { normal breast } \\
\text { tissues }(n=10)\end{array}$ & $\begin{array}{l}\text { Normal breast } \\
\text { tissues }(n=10)\end{array}$ & $\begin{array}{l}\text { Breast tumours } \\
\quad(n=120)\end{array}$ & $\begin{array}{c}\% \text { of underexpressed } \\
\text { tumours (mRNA } \\
\text { level }<0.33 \text { ) }\end{array}$ & $\begin{array}{l}\% \text { of normal } \\
\text { expressed } \\
\text { tumours }\end{array}$ & $\begin{array}{c}\% \text { of overexpressed } \\
\text { tumours (mRNA } \\
\text { level }>3 \text { ) }\end{array}$ \\
\hline CAMSAP1L1 & $27.84(25.16-29.6)^{a}$ & $1.00(0.53-1.55)^{b}$ & $1.02(0.26-27.10)^{b}$ & $1.67 \%$ & $97.50 \%$ & $0.83 \%$ \\
\hline CARS & $28.53(26.57-30.21)$ & $1.00(0.63-1.72)$ & $1.23(0.46-14.24)$ & $0.00 \%$ & $93.33 \%$ & $6.67 \%$ \\
\hline CPNE3 & 26.38 (24.37-27.75) & $1.00(0.77-1.36)$ & $1.43(0.34-17.15)$ & $0.00 \%$ & $89.17 \%$ & $10.83 \%$ \\
\hline CTSL1 & $27.18(25.58-27.95)$ & $1.00(0.42-2.46)$ & $1.11(0.35-14.87)$ & $0.00 \%$ & $94.17 \%$ & $5.83 \%$ \\
\hline FAM82B & $28.00(25.63-29.59)$ & $1.00(0.65-1.35)$ & $1.17(0,29-3.96)$ & $6.80 \%$ & $85.80 \%$ & $7.40 \%$ \\
\hline GGH & $28.99(27.43-30.56)$ & $1.00(0.52-1.45)$ & $1.79(0.19-13.94)$ & $2.50 \%$ & $68.33 \%$ & $29.17 \%$ \\
\hline GINS2 & $30.15(28.30-32.89)$ & $1.00(0.33-1.79)$ & $2.55(0,17-50.25)$ & $0.83 \%$ & $56.67 \%$ & $42.50 \%$ \\
\hline GPRC5A & $28.08(25.99-30.82)$ & $1.00(0.27-1.92)$ & $3.52(0,06-84.28)$ & $3.33 \%$ & $40.00 \%$ & $56.67 \%$ \\
\hline HIST1H2BK & $23.97(21.94-26.18)$ & $1.00(0.59-4.55)$ & $1.46(0.44-10.02)$ & $0.00 \%$ & $83.33 \%$ & $16.67 \%$ \\
\hline HRASLS & 31.89 (29.19-34.00) & $1.00(0.49-1.43)$ & $1.27(0-12.94)$ & $19.17 \%$ & $58.33 \%$ & $22.50 \%$ \\
\hline IMPA1 & $29.23(27.24-30.25)$ & $1.00(0.73-1.31)$ & $1.22(0.35-12.06)$ & $0.00 \%$ & $97.50 \%$ & $2.50 \%$ \\
\hline MMP1 & 34.89 (34.17-49.02) & $1.00(0-19.2)$ & $75.31(0-71.89)$ & $2.50 \%$ & $0.00 \%$ & $97.50 \%$ \\
\hline PTPN7 & $31.47(28.81-34.17)$ & $1.00(0.33-5.20)$ & $2.07(0.36-16.93)$ & $0.00 \%$ & $69.17 \%$ & $30.83 \%$ \\
\hline PXDN & $27.49(25.86-29.16)$ & $1.00(0.64-5.73)$ & $2.13(0.35-33.53)$ & $8.10 \%$ & $90.40 \%$ & $1.50 \%$ \\
\hline SFT2D2 & $26.22(23.96-27.93)$ & $1.00(0.68-1.22)$ & $0.74(0.27-7.67)$ & $2.50 \%$ & $95.83 \%$ & $1.67 \%$ \\
\hline TBC1D8 & $28.44(26.23-29.85)$ & $1.00(0.90-1.30)$ & $1.19(0.33-13.40)$ & $8.10 \%$ & $90.40 \%$ & $1.50 \%$ \\
\hline TPD52 & $27.03(24.13-28.93)$ & $1.00(0.56-1.77)$ & $3.73(0.83-47.30)$ & $0.00 \%$ & $35.83 \%$ & $64.17 \%$ \\
\hline $\mathrm{ZDHHC13}$ & $29.27(26.83-30.98)$ & $1.00(0.56-1.34)$ & $1.31(0.18-6.04)$ & $2.50 \%$ & $91,67 \%$ & $5.83 \%$ \\
\hline TNC & $27.38(25.73-31.20)$ & $1.00(0.16-1.80)$ & $0.74(0.07-30.81)$ & $25.00 \%$ & $60.83 \%$ & $14.17 \%$ \\
\hline VEGF165 & $29.17(26.76-30.20)$ & $1.00(0.61-1.68)$ & $1.89(0.35-16.43)$ & $0.00 \%$ & $73.33 \%$ & $26.67 \%$ \\
\hline VEGF189 & 30.55 (29.46-31.93) & $1.00(0.60-2.52)$ & $1.72(0-15,54)$ & $1.67 \%$ & $79.16 \%$ & $19.17 \%$ \\
\hline VEGFA & $28.21(26.62-29.71)$ & $1.00(0.69-2.15)$ & $1.82(0.42-13.37)$ & $0.00 \%$ & $72.50 \%$ & $27.50 \%$ \\
\hline \multicolumn{7}{|c|}{ 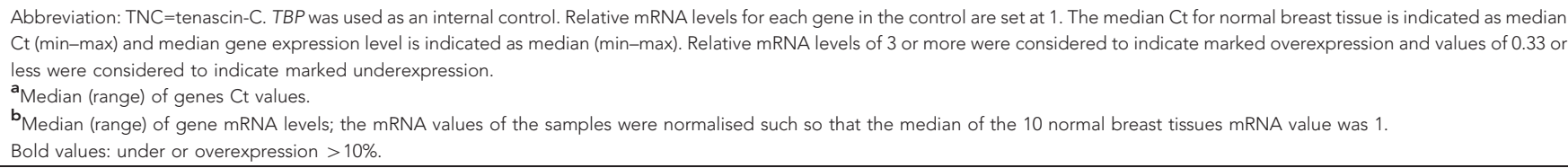 } \\
\hline
\end{tabular}

promoting the survival and outgrowth of micro-metastases in the lung, a finding highlighting the relevance of TNC as an ECM component of the metastatic niche (Oskarsson et al, 2011). The metalloproteinase MMP1 was shown to facilitate angiogenesis and to increase ECM degradation, two crucial processes for the invasive and migratory phenotype of tumour cells (Gialeli et al, 2011). MMP-1 level in tumour and stromal cells is significantly associated with tumour progression (Foley et al, 2012). When expressed in breast cancer cells, MMP-1 increases the assembly of new tumour blood vessels, the release of tumour cells into the bloodstream and the breaching of lung capillaries by circulating tumour cells to initiate lung metastasis (Gupta and Massagué, 2006; Foley et al, 2012).

Little is known about the differential expression and function of VEGF-A isoforms in human breast tumours. Transcriptomic analysis identified new genes expressed differentially in V165, V189 and cV clones. On the basis of the breast cancer metastasis gene signature (www.oncomine.org), we showed that those genes were specifically involved in metastasis formation. In addition, we carried out quantitative PCR to quantify the transcripts of those genes of interest in 120 breast tumours from patients with and without distant metastases. VEGF165 overexpression was detected in $26.7 \%$ of human breast cancer tumours, whereas VEGF189 overexpression was detected in $19.2 \%$ in our series of 120 tumours. High VEGF165 expression was correlated with poor prognosis in our series of 120 breast tumours (data not shown). VEGFA, GPRC5A and TBC1D8 low expression is also associated with the decrease of patient survival (Figure 5). However, although high VEGF189/VEGFA expression was significantly correlated with low expression of GPRC5A and TBC1D18, we could not significantly associate VEGF189 overexpression with poor prognosis, suggesting a complex regulation of these genes by VEGF189.

We found that VEGF189 increased cell adhesion to ECM (as previously described by Hervé et al, 2008) and reduced both invasion in the Matrigel assay and survival in stress conditions, as shown by comparison with VEGF165. Furthermore, the higher levels of apoptosis observed with VEGF189 in limiting culture conditions probably prevented many cells from surviving in the bloodstream or from remaining in the metastatic niche. The molecular basis of those differences is unknown. Neuropilin 1, a coreceptor for VEGF (Soker et al, 1998), is strongly expressed in several tumour cells, in which it has been implicated in cell migration and survival (Bachelder et al, 2001, 2003; Vintonenko et al, 2011; Perrot-Applanat and Di Benedetto, 2012). We recently showed that VEGF189 binds to NRP1 (Hervé et al, 2008), in addition to VEGF165. The affinity of VEGF189 for NRP1 appears to be stronger than that of VEGF165 (Vintonenko et al, 2011). NRP1 was also shown to interact with $\alpha 5 \beta 1$ integrin, enhancing pancreatic cancer cell survival and invasion (Fukasawa et al, 2007). In contrast in VEGF189 overexpressing cells, we found that VEGF189 bound to NRP-1 decreased breast cancer cell survival. (Vintonenko et al, 2011). Herein, we also demonstrated that VEGF189 autocrine effect on invasion was modulated through the NRP1 pathway as it was the case for survival (Vintonenko et al, 2011). Furthermore, these results were in accordance with those of our previous work demonstrating that sh-NRP-1 of VEGF189 clones resulted in the inhibition of UPA expression and activity. 


\begin{tabular}{|c|c|c|c|c|c|c|c|c|}
\hline \multicolumn{9}{|l|}{ A } \\
\hline & CAMSAP1L1 & Cars & CPNE3 & CTSL1 & FAM82B & GGH & GINS2 & GPRC5A \\
\hline $\begin{array}{l}\text { VEGF189/ } \\
\text { VEGFA }\end{array}$ & -0.112 & -0.381 & -0.226 & -0.138 & -0.052 & 0.24 & -0.273 & -0.219 \\
\hline \multirow[t]{2}{*}{$P$ value } & 0.22 & 0.000035 & 0.012 & 0.13 & 0.58 & 0.26 & 0.0027 & 0.016 \\
\hline & HIST1H2BK & HRASLS & IMPA1 & MMP1 & PTPN7 & PXDN & SFT2D2 & TBC1D8 \\
\hline $\begin{array}{c}\text { VEGF189/ } \\
\text { VEGFA }\end{array}$ & -0.338 & 0.064 & -0.057 & -0.02 & -0.112 & -0.116 & 0.05 & -0.181 \\
\hline \multirow[t]{2}{*}{$P$ value } & 0.00023 & 0.49 & 0.54 & 0.81 & 0.22 & 0.2 & 0.6 & 0.045 \\
\hline & TNC & TPD52 & VEGFA & VEGF165 & VEGF189 & $\begin{array}{l}\text { VEGF189/ } \\
\text { VEGFA }\end{array}$ & $\begin{array}{l}\text { VEGF165/ } \\
\text { VEGFA }\end{array}$ & $\mathrm{ZDHHC13}$ \\
\hline $\begin{array}{l}\text { VEGF189/ } \\
\text { VEGFA }\end{array}$ & 0.104 & -0.106 & 0.01 & -0.033 & 0.567 & 1 & -0.132 & -0.27 \\
\hline$P$ value & 0.26 & 0.145 & 0.91 & 0.72 & $<0.0000001$ & $<0.0000001$ & 0.15 & 0.003 \\
\hline
\end{tabular}

B
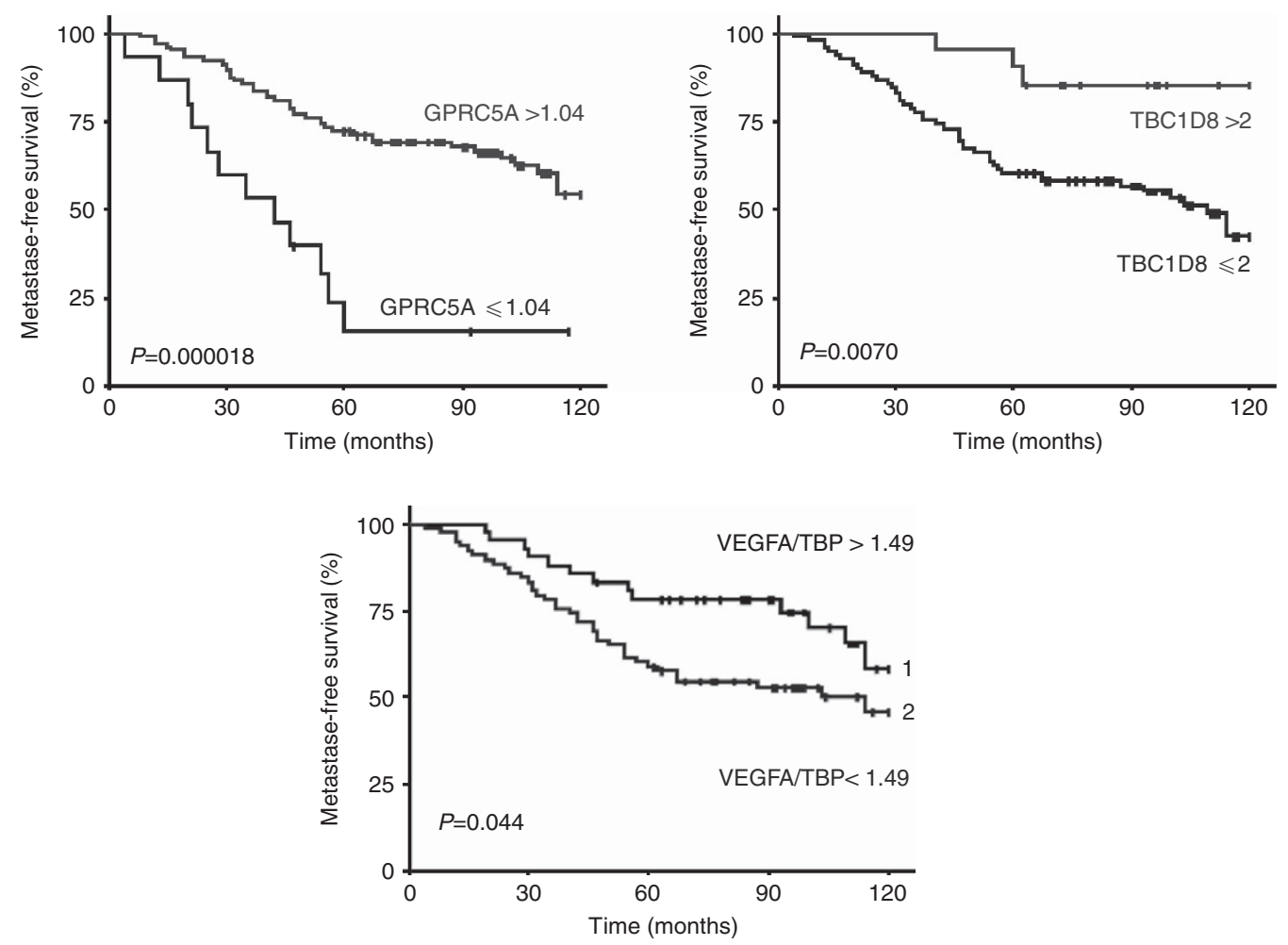

Figure 5. Statistical analysis of mRNA levels. (A) Spearman's rank correlation test for the genes of interest and the proportion of total VEGF-A in the form of VEGF189. Differences were considered significant if $P<0.05$. (B) Survival curves with an optimal cutoff point. Survival was estimated by the Kaplan-Meier method, and groups were compared in log-rank tests. The optimal cutoff point was calculated for each gene and used to distinguish two groups as described in Materials and methods.

Survival is more important for colonisation than proliferation, particularly in the bloodstream. These properties may account for the lower levels of colonisation observed with V189 than with V165 clones in the first steps. Cell migration and invasion result from a balance between cell adhesion and detachment, both of which are required for motility. If the adhesion force is too strong, the cells attach tightly to the substrate and are unable to disperse. The greater adhesion of cells to the ECM with the VEGF189 clone, previously reported by Hervé et al (2008), is thus also consistent with a lower capacity of the cells to invade distant organs and to colonise. Furthermore, the higher levels of apoptosis observed with VEGF189 in limiting culture conditions probably prevented many cells from surviving in the bloodstream or from remaining in the metastatic niche.

In conclusion, we found that overexpression of VEGF189 results in fewer mice with colonisation in the lungs and bone than
VEGF165 overexpression. Our results are important as they suggest that the nature of overexpressed VEGF isoform influences tissue colonisation by tumour cell, in a different manner.

\section{ACKNOWLEDGEMENTS}

We thank P Balaguer (INSERM U896, Montpellier, France) for providing the plasmid expressing the luciferase gene and the hygromycin resistance gene, and E. Savariau for micrografts. We also thank J-P Jais (Bioinformatics platform, Necker Institute, Paris) for transcriptomic analysis. Aurore Toullec $\mathrm{PhD}$ was supported by a grant from the Ile-de-France Region. We thank Alexandra Becquet, $\mathrm{PhD}$, for having proofread and edited the English language in our manuscript. 


\section{CONFLICT OF INTEREST}

The authors declare no conflict of interest.

\section{REFERENCES}

Abdelkarim M, Guenin E, Sainte-Catherine O, Vintonenko N, Peyri N, Perret GY, Crepin M, Khatib AM, Lecouvey M, Di Benedetto M (2009) New symmetrically esterified m-bromobenzyl non-aminobisphosphonates inhibited breast cancer growth and metastases. PLos One 4: e4685.

Ancelin M, Buteau-Lozano H, Meduri G, Osborne-Pellegrin M, Sordello S, Plouët J, Perrot-Applanat M (2002) A dynamic shift of VEGF isoforms with a transient and selective progesterone-induced expression of VEGF189 regulates angiogenesis and vascular permeability in human uterus. Proc Natl Acad Sci USA 99: 6023-6028.

Bachelder RE, Crago A, Chung J, Wendt MA, Shaw LM, Robinson G, Mercurio AM (2001) Vascular endothelial growth factor is an autocrine survival factor for neuropilin-expressing breast carcinoma cells. Cancer Res 61: 5736-5740.

Bachelder RE, Lipscomb EA, Lin X, Wendt MA, Chadborn NH, Eickholt BJ, Mercurio AM (2003) Competing autocrine pathways involving alternative neuropilin-1 ligands regulate chemotaxis of carcinoma cells. Cancer Res 63: $5230-5233$

Bloom HJ, Richardson WW (1957) Histological grading and prognosis in breast cancer; a study of 1409 cases of which 359 have been followed for 15 years. Br J Cancer 11: 359-377.

Bos PD, Nguyen DX, Massagué J (2010) Modeling metastasis in the mouse. Curr Opin Pharmacol 10: 571-577.

Dandachi N, Hauser-Kronberger C, Moré E, Wiesener B, Hacker GW, Dietze O, Wirl G (2001) Co-expression of tenascin-C and vimentin in human breast cancer cells indicates phenotypic transdifferentiation during tumor progression: correlation with histopathological parameters, hormone receptors, oncoproteins. J Pathol 193: 181-189.

Edgar R, Domrachev M, Lash AE (2002) Gene Expression Omnibus: NCBI gene expression and hybridization array data repository. Nucleic Acids Res 30: $207-210$.

El-Mabhouh AA, Nation PN, Kaddoura A, Mercer JR (2008) Unexpected preferential brain metastases with a human breast tumor cell line MDAMB-231 in BALB/c nude mice. Vet Pathol 45: 941-944.

Ferrara N, Davis-Smyth T (1997) The biology of vascular endothelial growth factor. Endocr Rev 18: 4-25.

Foley CJ, Luo C, O'Callaghan K, Hinds PW, Covic L, Kuliopulos A (2012) Matrix metalloprotease-1a promotes tumorigenesis and metastasis. J Biol Chem 287(29): 24330-24338.

Folkman J (1995) Angiogenesis in cancer, vascular, rheumatoid and other disease. Nat Med 1: 27-31.

Fukasawa M, Matsushita A, Korc M (2007) Neuropilin-1 interacts with integrin betal and modulates pancreatic cancer cell growth, survival and invasion. Cancer Biol Ther 6: 1173-1180.

Gialeli C, Theocharis AD, Karamanos NK (2011) Roles of matrix metalloproteinases in cancer progression and their pharmacological targeting. FEBS J 278: 16-27.

Gille H, Kowalski J, Li B, LeCouter J, Moffat B, Zioncheck TF, Pelletier N, Ferrara N (2001) Analysis of biological effects and signaling properties of Flt-1 (VEGFR-1) and KDR (VEGFR-2). A reassessment using novel receptor-specific vascular endothelial growth factor mutants. J Biol Chem 276: 3222-3230.

Gitay-Goren H, Soker S, Vlodavsky I, Neufeld G (1992) The binding of vascular endothelial growth factor to its receptors is dependent on cell surface-associated heparin-like molecules. J Biol Chem 267: 6093-6098.

Grunstein J, Masbad JJ, Hickey R, Giordano F, Johnson RS (2000) Isoforms of vascular endothelial growth factor act in a coordinate fashion to recruit and expand tumor vasculature. Mol Cell Biol 20: 7282-7291.

Gupta GP, Massagué J (2006) Cancer metastasis: building a framework. Cell 127: 679-695.

Hervé M-A, Buteau-Lozano H, Mourah S, Calvo F, Perrot-Applanat M (2005) VEGF189 stimulates endothelial cells proliferation and migration in vitro and up-regulates the expression of Flk-1/KDR mRNA. Exp Cell Res 309: 24-31.

Hervé MA, Buteau-Lozano H, Vassy R, Bieche I, Velasco G, Pla M, Perret G, Mourah S, Perrot-Applanat M (2008) Overexpression of vascular endothelial growth factor 189 in breast cancer cells leads to delayed tumor uptake with dilated intratumoral vessels. Am J Pathol 172: 167-178.

Irizarry RA, Hobbs B, Collin F, Beazer-Barclay YD, Antonellis KJ, Scherf U, Speed TP (2003) Exploration, normalisation, and summaries of high density oligonucleotide array probe level data. Biostatistics 4: 249-264.

Jacobsen J, Grankvist K, Rasmuson T, Ljungberg B (2006) Different isoform patterns for vascular endothelial growth factor between clear cell and papillary renal cell carcinoma. BJU Int 97: 1102-1108.

Jenkins DE, Hornig YS, Oei Y, Dusich J, Purchio T (2005) Bioluminescent human breast cancer cell lines that permit rapid and sensitive in vivo detection of mammary tumors and multiple metastases in immune deficient mice. Breast Cancer Res 7: R444-R454.

Lee TH, Seng S, Sekine M, Hinton C, Fu Y, Avraham HK, Avraham S (2007) Vascular endothelial growth factor mediates intracrine survival in human breast carcinoma cells through internally expressed VEGFR1/FLT1. PLoS Med 4: e186.

Lee YH, Tokunaga T, Oshika Y, Suto R, Yanagisawa K, Tomisawa M, Fukuda H, Nakano H, Abe S, Tateishi A, Kijima H, Yamazaki H, Tamaoki N, Ueyama Y, Nakamura M (1999) Cell-retained isoforms of vascular endothelial growth factor (VEGF) are correlated with poor prognosis in osteosarcoma. Eur J Cancer 35: 1089-1093.

Mackie EJ, Chiquet-Ehrismann R, Adams Pearson C, Inaguma Y, Taya K, Kawarada Y, Sakakura T (1987) Tenascin is a stromal marker for epithelial malignancy in the mammary gland. Proc Natl Acad Sci USA 84: 4621-4625.

Matsuyama M, Chijiwa T, Inoue Y, Abe Y, Nishi M, Miyazaki N, Furukawa D, Mukai M, Suemizu H, Sekido Y, Ueyama Y, Nakamura M (2009) Alternative splicing variant of vascular endothelial growth factor-A is a critical prognostic factor in non-small cell lung cancer. Oncol Rep 22: 1407-1413.

Minn AJ, Kang Y, Serganova I, Gupta GP, Giri DD, Doubrovin M, Ponomarev V, Gerald WL, Blasberg R, Massagué J (2005) Distinct organ-specific metastatic potential of individual breast cancer cells and primary tumors. J Clin Invest 115: 44-55.

Neufeld G, Cohen T, Gengrinovitch S, Poltorak Z (1999) Vascular endothelial growth factor (VEGF) and its receptors. FASEB J 13: 9-22.

Orimo A, Gupta PB, Sgroi DC, Arenzana-Seisdedos F, Delaunay T, Naeem R, Carey VJ, Richardson AL, Weinberg RA (2005) Stromal fibroblasts present in invasive human breast carcinomas promote tumor growth and angiogenesis through elevated SDF-1/CXCL12 secretion. Cell 121: 335-348.

Oshika Y, Nakamura M, Tokunaga T, Ozeki Y, Fukushima Y, Hatanaka H, Abe Y, Yamazaki H, Kijima H, Tamaoki N, Ueyama Y (1998) Expression of cell-associated isoform of vascular endothelial growth factor 189 and its prognostic relevance in non-small cell lung cancer. Int J Oncol 12: 541-544.

Oskarsson T, Acharyya S, Zhang XH, Vanharanta S, Tavazoie SF, Morris PG, Downey RJ, Manova-Todorova K, Brogi E, Massagué J (2011) Breast cancer cells produce tenascin $\mathrm{C}$ as a metastatic niche component to colonize the lungs. Nat Med 17: 867-874.

Park JE, Keller GA, Ferrara N (1993) The vascular endothelial growth factor (VEGF) isoforms: differential deposition into the subepithelial extracellular matrix and bioactivity of extracellular matrix-bound VEGF. Mol Biol Cell 4: 1317-1326.

Perrot-Applanat M, Di Benedetto M (2012) Autocrine functions of VEGF in breast tumor cells: Adhesion, survival, migration and invasion. Cell Adh Migr 6(6): 547-553.

Plouët J, Moro F, Bertagnolli S, Coldeboeuf N, Mazarguil H, Clamens S, Bayard F (1997) Extracellular cleavage of the vascular endothelial growth factor 189 -amino acid form by urokinase is required for its mitogenic effect. J Biol Chem 272: 13390-13396.

Price JE (2010) Metastasis from human breast cancer cell lines. Breast Cancer Res Treat 39: 93-102.

Richardson AL, Wang ZC, De Nicolo A, Lu X, Brown M, Miron A, Liao X, Iglehart JD, Livingston DM, Ganesan S (2006) X chromosomal abnormalities in basal-like human breast cancer. Cancer Cell 9: 121-132.

Ruhrberg C, Gerhardt H, Golding M, Watson R, Ioannidou S, Fujisawa H, Betsholtz C, Shima DT (2002) Spatially restricted patterning cues provided by heparin-binding VEGF-A control blood vessel branching morphogenesis. Genes Dev 16: 2684-2698.

Smyth GK (2005) Limma: linear models for microarray data. In: Bioinformatics and Computational Biology Solutions using $R$ and Bioconductor, R. Gentleman, Carey V, Dudoit S, Irizarry R, Huber W (eds) pp 397-420. Springer: New York, USA. 
Soker S, Takashima S, Miao HQ, Neufeld G, Klagsbrun M (1998) Neuropilin1 is expressed by endothelial and tumor cells as an isoform-specific receptor for vascular endothelial growth factor. Cell 92: 735-745.

Steeg PS (2006) Tumor metastasis: mechanistic insights and clinical challenges. Nat Med 12: 895-904.

Tischer E, Mitchell R, Hartman T, Silva M, Gospodarowicz D, Fiddes JC, Abraham JA (1991) The human gene for vascular endothelial growth factor. Multiple protein forms are encoded through alternative exon splicing. J Biol Chem 266: 11947-11954.

Tokunaga T, Oshika Y, Abe Y, Ozeki Y, Sadahiro S, Kijima H, Tsuchida T, Yamazaki H, Ueyama Y, Tamaoki N, Nakamura M (1998) Vascular endothelial growth factor (VEGF) mRNA isoform expression pattern is correlated with liver metastasis and poor prognosis in colon cancer. Br J Cancer 77: 998-1002.

Tomii Y, Yamazaki H, Sawa N, Ohnishi Y, Kamochi J, Tokunaga T, Osamura Y, Sadahiro S, Kijima H, Abe Y, Ueyama Y, Tamaoki N, Nakamura M (2002) Unique properties of 189 amino acid isoform of vascular endothelial growth factor in tumorigenesis.Int. J Oncol 21: 1251-1257.

Tozer GM, Akerman S, Cross NA, Barber PR, Björndahl MA, Greco O, Harris S, Hill SA, Honess DJ, Ireson CR, Pettyjohn KL, Prise VE, Reyes-Aldasoro CC, Ruhrberg C, Shima DT, Kanthou C (2008) Blood vessel maturation and response to vascular-disrupting therapy in single vascular endothelial growth factor-A isoform-producing tumors. Cancer Res 68: 2301-2311.

Vintonenko N, Pelaez-Garavito I, Buteau-Lozano H, Toullec A, Lidereau R, Perret GY, Bieche I, Perrot-Applanat M (2011) Overexpression of VEGF189 in breast cancer cells induces apoptosis via NRP1 under stress conditions. Cell Adh Migr 5: 332-343.

Wang Y, Klijn JG, Zhang Y, Sieuwerts AM, Look MP, Yang F, Talantov D, Timmermans M, Meijer-van Gelder ME, Yu J, Jatkoe T, Berns EM, Atkins D, Foekens JA (2005) Gene-expression profiles to predict distant metastasis of lymph-node-negative primary breast cancer. Lancet 365: 671-679.

Workman P, Aboagye EO, Balkwill F, Balmain A, Bruder G, Chaplin DJ, Double JA, Everitt J, Farningham D, Glennie MJ, Kelland LR, Robinson V,
Stratford IJ, Tozer GM, Watson S, Wedge SR, Eccles SA. An ad hoc committee of the National Cancer Research institute (2010) Guidelines for the welfare and use of animals in cancer research. Br J Cancer 102: $1555-1577$.

Yoneda T, Williams PJ, Hiraga T, Niewolna M, Nishimura R (2001) A boneseeking clone exhibits different biological properties from the MDA-MB231 parental human breast cancer cells and a brain-seeking clone in vivo and in vitro. J Bone Miner Res 16: 1486-1495.

Yu JL, Rak JW, Klement G, Kerbel RS (2002) Vascular endothelial growth factor isoform expression as a determinant of blood vessel patterning in human melanoma xenografts. Cancer Res $\mathbf{6 2}$ : $1838-1846$.

Yuan A, Yu CJ, Kuo SH, Chen WJ, Lin FY, Luh KT, Yang PC, Lee YC (2001) Vascular endothelial growth factor 189 mRNA isoform expression specifically correlates with tumor angiogenesis, patient survival, and postoperative relapse in non-small-cell lung cancer. J Clin Oncol 19: $432-441$.

Yuan A, Lin CY, Chou CH, Shih CM, Chen CY, Cheng HW, Chen YF, Chen JJ, Chen JH, Yang PC, Chang C (2011) Functional and structural characteristics of tumor angiogenesis in lung cancers overexpressing different VEGF isoforms assessed by DCE- and SSCE-MRI. PLoS One 6 : e16062.

Zhang HT, Scott PA, Morbidelli L, Peak S, Moore J, Turley H, Harris AL, Ziche M (2000) The 121 amino acid isoform of vascular endothelial growth factor is more strongly tumorigenic than other splice variants in vivo. Br J Cancer 83: 63-68.

This work is published under the standard license to publish agreement. After 12 months the work will become freely available and the license terms will switch to a Creative Commons AttributionNonCommercial-Share Alike 4.0 Unported License.

Supplementary Information accompanies this paper on British Journal of Cancer website (http://www.nature.com/bjc) 